\title{
A PROSPECTIVE STUDY OF SOME MEDICO-LEGAL ASPECTS OF VIOLENCE AGAINST MARRIED WOMEN ARRIVED AT MENOUFIA UNIVERSITY HOSPITAL
}

\author{
Ola Abdel Hady Sweilum, Situhom Elsayed Elagamy \\ Forensic Medicine and Clinical Toxicology Department, Faculty of Medicine- Menoufia \\ University. \\ Corresponding author: Ola Abdel Hady Sweilum (olaahady@hotmail.com) (Tel. \\ 01019898260), Al Rehab city, Cairo, Egypt.
}

\begin{abstract}
Violence is defined as the behaviours of frightening, threatening, or annoying that are used to impose one's power on others. Violence against women is prevalent all over the world especially the developing countries. It is one of the main causes of morbidity between women. The aim of the present study is to evaluate the magnitude of the problem of violence against Egyptian married women and factors affecting it and to identify the risk factors of the repeated violence against them by their husbands. The study was conducted on 311 married women and we found that violence against women was more significantly related to women aged 21-30 years, women who read and write, housewives, women who lives in rural area; the social problems were the main cause of violence and physical injuries were higher than sexual, blunt agents were the most commonly used ones. As regards to the assailant, non-husband assailants were the most common, and age 21-30 was the commonest age. Outdoor violence was more common than indoor one. The total number of women exposed to violence from their husbands was 94 that represented $30.2 \%$ of total women exposed to violence. $72(76.6 \%)$ of them exposed to violence repeatedly. There was a statistically significant difference between women education (read \& write), husband age (21-30 years), husband occupation (not working), husband special habits, duration of marriage ( $<5$ years), number of children ( $>3$ kids) and the frequency of husband violence (once and repeated).Low level of female education and husbands have special habits are the most dependent factors increase the frequency of husband violence against their wives.
\end{abstract}

Key words: Violence, Married women, Special habits, Repeated violence, Husband assailant.

\section{INTRODUCTION}

Violence is defined as the behaviours of frightening, threatening, or annoying that are used to impose one's power on others (Roberts, 2005). Women are prone to it 6 times more than men as have been showed by many studies (Watts \& Zimmerman 2002).

Violence against women is prevalent all over the world especially the developing countries (Jahromi et al., 2016).

It affects millions of women lives across all socioeconomic and educational classes. It occurs in all society sections, irrespective of race, ethnicity, religion, or sex. Physical abuse, sexual abuse, emotional abuse, economic deprivation, and threats are its most common forms (Yildizhan et al., 2009). 
The household dignity and privacy maintenance traditions have kept this type of violence hidden from scrutiny (Michael et al., 2006). Women are not only victims to their husbands but also to both natal and marital homes members and surroundings (Majumdar 2006).

According to the United Nations, violence is experienced against women widely and can lead to serious health problems for them including death, as it is one of the main causes of morbidity between women (United Nations2006 \& Raje 2015).

These health problems can be a wide range of physical and mental consequences which could be in short or long term (Petersen et al., 2001). Physical and sexual violence have been associated with many psychiatric complications as depression, anxiety, phobias, post-traumatic stress disorder, and suicidal attempts (Bonomi et al., 2006 \& Patel et al., 2006).

\section{MATERIAL \& METHOD}

This study is a prospective study, conducted on a random sample of married women of different age groups, came to Forensic medicine department in Menoufia Faculty of medicine Hospital, Egypt to do a primary medico-legal report over one year of study (between 1st June 2016 to end of May 2017).

The study was performed using a modified domestic violence questionnaire and based on previous studies. The consent was obtained (verbal consent) from the studied women to participate in the study after explaining them the purpose of it. The Questionnaires were written for illiterate women. Widows and Divorced women were excluded. The
Questionnaire divided into two parts: The first part filled by all married women exposed to violence, and including their age, residence, occupation, education, type of assailant, assailant age, place of violence, cause of violence, type of violence and agents used in physical violence. The second part was filled by married women exposed to violence from their husbands and stressed on the frequency of husband violence (once or repeated) and includes women age, education, occupation, (which was asked in the first part), husband age, education, occupation, special habits, duration of marriage and number of children. It also includes the types of husband violence (which asked before in the first part).

Research Ethical Committee of Faculty of medicine, Menoufia University approved the study. Collected data was statistically analysed.

Statistical analysis: Data were fed to the computer and analysed using IBM SPSS software package version 20.0. Data were fed to the computer and analysed using IBM SPSS software package version 20.0. (Armonk, NY: IBM Corp). Comparisons between groups for categorical variables were assessed using Chi-square test goodness of fit. Multivariate analysis logistic regression was used to detect the most independent/ affecting factor for repeated husband violence. Significance of the obtained results was judged at the 5\% level.

\section{RESULTS}

The total number of married women exposed to violence and arrived at forensic medicine department at Menoufia University Hospital to get a 
primary medico legal report over the study period (between June 2016 and May 2017) was 311.

As regards the age of married women, most of women exposed to violence (46\%) were among 21-30 years old, the least exposed women were above 40 years old $(11.6 \%)$. The difference between women age groups regarding violence exposure was statistically highly significant $(\mathrm{P}$ $<0.001$ ) (Table 1).

Women who received moderate education (obligatory or secondary) and who read and write represented the highest percentage $(34.7 \%$ and $33.4 \%$ respectively) of those exposed to violence, and women who received university education represented the least percentage (12.9\%). This difference was statistically significant (P value <0.001) (Table 1).

$65.9 \%$ of married women exposed to violence were housewives. The difference between women regards occupation was statistically highly significant ( $\mathrm{P}$ value <0.001) (Table 1).

Married women exposed to violence were mainly rural dwellers $(72.3 \%)$ and the difference in residence was statistically highly significant ( $P$ value <0.001) (Table 1).

The main cause for violence against married women was social $(62.7 \%)$, followed by combined causes (more than one cause) which represented 17\%, economic cause represented $14.5 \%$ and ignorance (sexual in the form of rape and buggery) represented $5.8 \%$. This difference was statistically significant (P value <0.001) (Table 1).

Husband was the assailant in $30.2 \%$ of violence cases, while nonhusband assailants (Neighbors, work colleagues, relatives ....) represented
69.8\%. This difference was statistically highly significant ( $\mathrm{P}$ value $<0.001$ ) (Table 1).

Regarding the assailant age, assailants aged between 21-30 years were the highest $(38.9 \%)$. The difference between assailant's age was statistically highly significant (P $<0.001$ ) (Table 1). The most common type of violence was physical type $(93.6 \%)$. Sexual violence represented $6.4 \%$. The difference was statistically highly significant ( $\mathrm{P}$ value $<0.001)$ (Table 1) (Figure 5, 6).In physical violence, blunt agents used in $78.1 \%$ of cases. This difference was statistically significant ( $\mathrm{P}$ value $<0.001$ ) (Table 1).More than half of women exposed to violence outdoor (60.1\%). This difference was statistically significant ( $\mathrm{P}$ value $<0.001)$ (Table 1).

The total number of women exposed to violence from their husbands was 94, that represents $30.2 \%$ of total women exposed to violence (85 of them exposed to physical violence and 9 of them were exposed to sexual violence in the form of buggery). 72 women (76.6\%) of them exposed to violence repeatedly. There was a statistically significant difference between women education (read \& write and moderate education), husband age (21-30 and 31-40 years), husband occupation (not working), husband special habits, duration of marriage ( $<5$ years), number of children ( $>3$ kids) and the rate of violence against women by their husbands (once and repeated) as $\mathrm{P}$ values were $0.04,0.04,0.03,0.02$, $0.02,0.04$ respectively. While it was no statistical significant difference regarding women age, occupation, and husband education (Table 2). 
By applying the multivariate logistic regression, it was found that low level of female education and husbands have special habits are the most dependent factors increase the frequency of husband violence against their wives (Table 3).

According to the legal classification of injuries, the most common types was simple type as it represented $91.4 \%$, followed by dangerous type $(7.9 \%)$ and fatal type $(0.69 \%)$ (Figure 1).
Contusions were the commonest type of physical injuries (76.2\%) followed by Abrasions, wounds (contused, cut and stab), chemical and the least were firearm wounds $(1.4 \%)$ (Figure2,4). Special habits (single or mixed) of husbands were mainly smoking which represented the most common special habits $(75.9 \%)$ followed by tramadol, hashish, other drugs (Benzodiazepines, codeine) and finally alcohol respectively (Figure 3).

Table (1): Statistical analysis of the Distribution of the women exposed to violence.

\begin{tabular}{|c|c|c|}
\hline & No. $(\%)$ & p \\
\hline \multicolumn{3}{|l|}{ Woman age } \\
\hline$<20$ & $44(14.1 \%)$ & \multirow[t]{4}{*}{$<0.001^{*}$} \\
\hline $21-30$ & $143(46 \%)$ & \\
\hline $31-40$ & $88(28.3 \%)$ & \\
\hline$>40$ & $36(11.6 \%)$ & \\
\hline \multicolumn{3}{|c|}{ Women occupation } \\
\hline Housewife & $205(65.9 \%)$ & \multirow[t]{2}{*}{$<0.001^{*}$} \\
\hline Working & $106(34.08 \%)$ & \\
\hline \multicolumn{3}{|c|}{ Women education } \\
\hline Illiterate & $59(18.97 \%)$ & \multirow[t]{4}{*}{$<0.001^{*}$} \\
\hline Read and write & $104(33.44 \%)$ & \\
\hline Moderate & $108(34.73 \%)$ & \\
\hline University & $40(12.86 \%)$ & \\
\hline \multicolumn{3}{|l|}{ Residence } \\
\hline Rural & $225(72.3 \%)$ & \multirow[t]{2}{*}{$<0.001^{*}$} \\
\hline Urban & $86(27.7 \%)$ & \\
\hline \multicolumn{3}{|l|}{ Assailant } \\
\hline Non-husband & $217(69.8 \%)$ & \multirow[b]{2}{*}{$<0.001 *$} \\
\hline Husband & $94(30.2 \%)$ & \\
\hline \multicolumn{3}{|l|}{ Assailant age } \\
\hline$<20$ & $50(16.1 \%)$ & \multirow[t]{5}{*}{$<0.001^{*}$} \\
\hline $21-30$ & $121(38.9 \%)$ & \\
\hline $31-40$ & $78(25.1 \%)$ & \\
\hline$>40$ & $43(13.8 \%)$ & \\
\hline Unknown & $19(6.1 \%)$ & \\
\hline \multicolumn{3}{|l|}{ Place } \\
\hline Indoor & $124(39.9 \%)$ & \multirow[b]{2}{*}{$<0.001 *$} \\
\hline Out door & $187(60.1 \%)$ & \\
\hline Cause & & \\
\hline
\end{tabular}




\begin{tabular}{|l|l|l|}
\hline Social & $195(62.7 \%)$ & \\
\hline Economic & $45(14.5 \%)$ & \\
\hline Combined & $53(17 \%)$ & \multirow{2}{*}{$<0.001^{*}$} \\
\hline Other & $18(5.8 \%)$ & \\
\hline Violence type & & \multirow{2}{*}{$<0.001^{*}$} \\
\hline Sexual & $20(6.4 \%)$ & \\
\hline Physical & $291(93.6 \%)$ & \multirow{2}{*}{$<0.001^{*}$} \\
\cline { 1 - 2 } Agent of physical violence & & \\
\hline Blunt & $243(78.1 \%)$ & \\
\cline { 1 - 2 } Sharp & $39(12.5 \%)$ & \\
\hline Firearm & $4(1.3 \%)$ & \\
\cline { 1 - 2 } Chemical & $5(1.6 \%)$ & \\
\cline { 1 - 2 }
\end{tabular}

Qualitative data were described using number and percent and was compared using Chi square of goodness of fit.

$*$ : Statistically significant at $\mathrm{p} \leq 0.05$ 
Table (2): Statistical analysis of the Relation between repeated violence against married women by their husbands and different affecting parameters $(n=94)$.

\begin{tabular}{|c|c|c|c|c|}
\hline \multirow{3}{*}{$\begin{array}{l}\text { Woman age } \\
\end{array}$} & \multicolumn{2}{|c|}{ Frequency in husband violence } & & \multirow[t]{2}{*}{$\mathbf{p}$} \\
\hline & \multirow[t]{2}{*}{$\begin{array}{c}\text { Once } \\
(n=22)\end{array}$} & \multirow[t]{2}{*}{$\begin{array}{c}\text { Repeated } \\
(n=72)\end{array}$} & & \\
\hline & & & & \\
\hline$<20$ & $6(27.3 \%)$ & $16(72.7 \%)$ & & 0.77 \\
\hline $21-30$ & $10(23.8 \%)$ & $32(76.2 \%)$ & & \\
\hline $31-40$ & $6(22.2 \%)$ & $21(77.7 \%)$ & & \\
\hline$>40$ & $0(0 \%)$ & $3(100 \%)$ & & \\
\hline \multicolumn{5}{|c|}{ Women occupation } \\
\hline Housewife & $18(28.13 \%)$ & $46(71.88 \%)$ & & \multirow[t]{2}{*}{0.11} \\
\hline Working & $4(13.33 \%)$ & $26(86.67 \%)$ & & \\
\hline \multicolumn{5}{|c|}{ Women education } \\
\hline Illiterate & $6(30 \%)$ & $14(70 \%)$ & 0.552 & $0.04 *$ \\
\hline *Read and write & $6(12.24 \%)$ & $43(87.76 \%)$ & & $0.008^{*}$ \\
\hline *Moderate & $9(42.86 \%)$ & $12(57.14 \%)$ & & $0.037^{*}$ \\
\hline University & $1(25 \%)$ & $3(75 \%)$ & 1.000 & \\
\hline \multicolumn{5}{|c|}{ Husband occupation } \\
\hline *Not Working & $4(11.1 \%)$ & $32(88.9 \%)$ & & \multirow[t]{2}{*}{$0.03^{*}$} \\
\hline Working & $18(31.0 \%)$ & $40(69 \%)$ & & \\
\hline \multicolumn{5}{|c|}{ Husband special habits } \\
\hline No & $13(36.1 \%)$ & $23(63.9 \%)$ & & \multirow[t]{2}{*}{$0.02 *$} \\
\hline *Yes & $9(15.5 \%)$ & $49(84.5 \%)$ & & \\
\hline \multicolumn{5}{|c|}{ Husband education } \\
\hline Illiterate & $5(35.7 \%)$ & $9(64.3 \%)$ & & \multirow[t]{4}{*}{0.17} \\
\hline Read and write & $7(35 \%)$ & $13(65 \%)$ & & \\
\hline Moderate & $6(13.6 \%)$ & $38(86.4 \%)$ & & \\
\hline High & $4(25 \%)$ & $12(75 \%)$ & & \\
\hline \multicolumn{5}{|l|}{ Husband age } \\
\hline$<20$ & $3(37.5 \%)$ & $5(62.5 \%)$ & 0.385 & \\
\hline$* 21-30$ & $5(11.9 \%)$ & $37(88.1 \%)$ & $0.018^{*}$ & $0.04^{*}$ \\
\hline$* 31-40$ & $12(38.7 \%)$ & $19(61.3 \%)$ & $0.014^{*}$ & \\
\hline$>40$ & $2(15.4 \%)$ & $11(84.6 \%)$ & 0.726 & \\
\hline \multicolumn{5}{|l|}{ No of children } \\
\hline Non & $6(22.2 \%)$ & $21(77.8 \%)$ & & $0.04 *$ \\
\hline$<3$ & $12(37.5 \%)$ & $20(62.5 \%)$ & & \\
\hline$*>3$ & $4(11.4 \%)$ & $31(88.6 \%)$ & & \\
\hline \multicolumn{5}{|c|}{ Duration of marriage } \\
\hline$*<5$ & $5(12.2 \%)$ & $36(87.8 \%)$ & & \multirow[t]{2}{*}{$0.02^{*}$} \\
\hline$>5$ & $17(32.1 \%)$ & $36(67.9 \%)$ & & \\
\hline
\end{tabular}

Qualitative data were described using number and percent and was compared using Chi square test or Fisher Exact test, *: Statistically significant at $\mathbf{p} \leq 0.05$ 
Table (3): Multivariate analysis logistic regression for repeated violence against married women by their husbands.

\begin{tabular}{|l|c|c|}
\hline & OR & Sig. \\
\hline Female education (low education) & $1.953^{*}$ & $0.007^{*}$ \\
\hline Husband occupation (Not working) & 1.227 & 0.142 \\
\hline Husband special habits & $1.680^{*}$ & $0.015^{*}$ \\
\hline Husband age & & \\
\hline $21-30$ & 1.154 & 0.282 \\
\hline No of children (>3) & 1.033 & 0.367 \\
\hline Duration of marriage $(<\mathbf{5})$ & -1.286 & 0.243 \\
\hline
\end{tabular}

OR: Odds ratio

Low education (Illiterate + read and write)

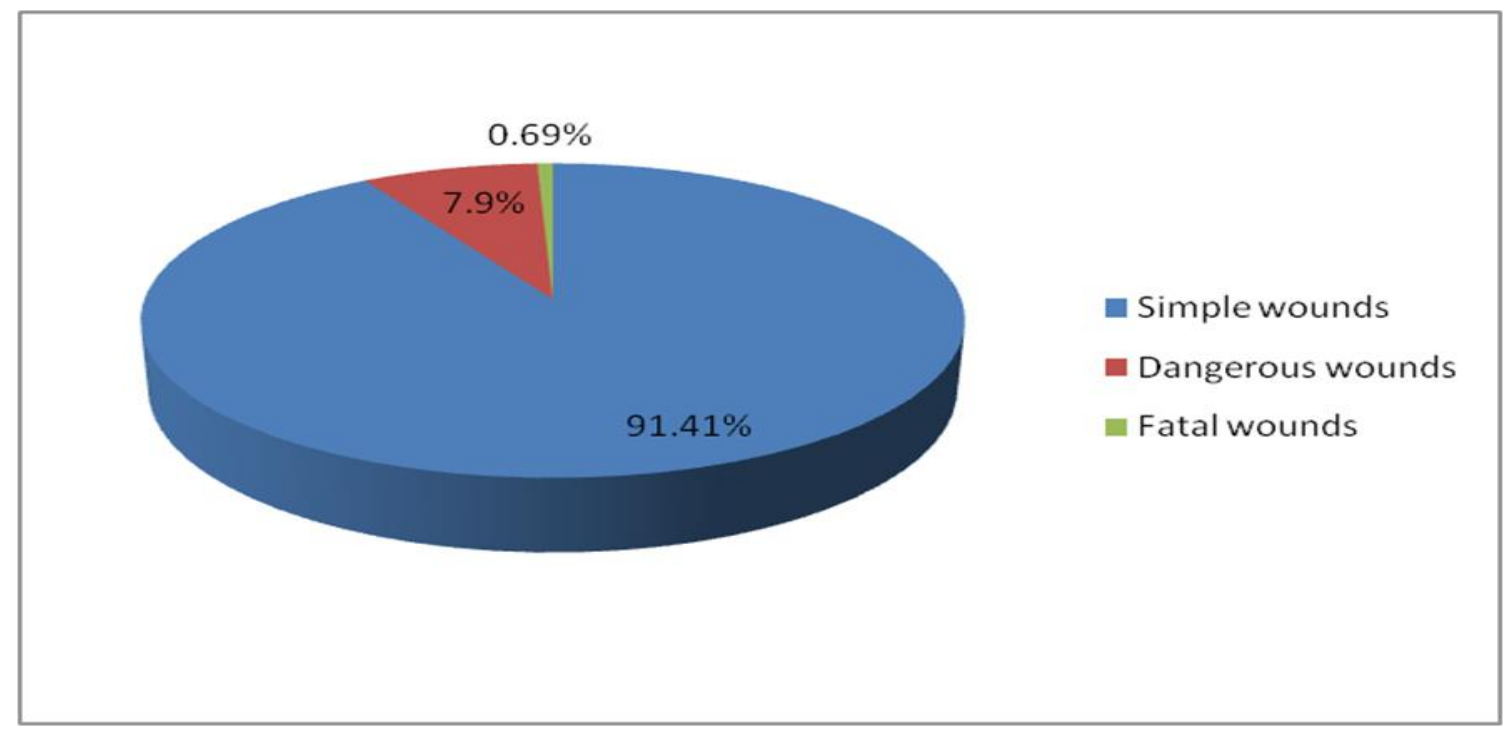

Figure. (1): Severity of physical injuries (According to legal classification).

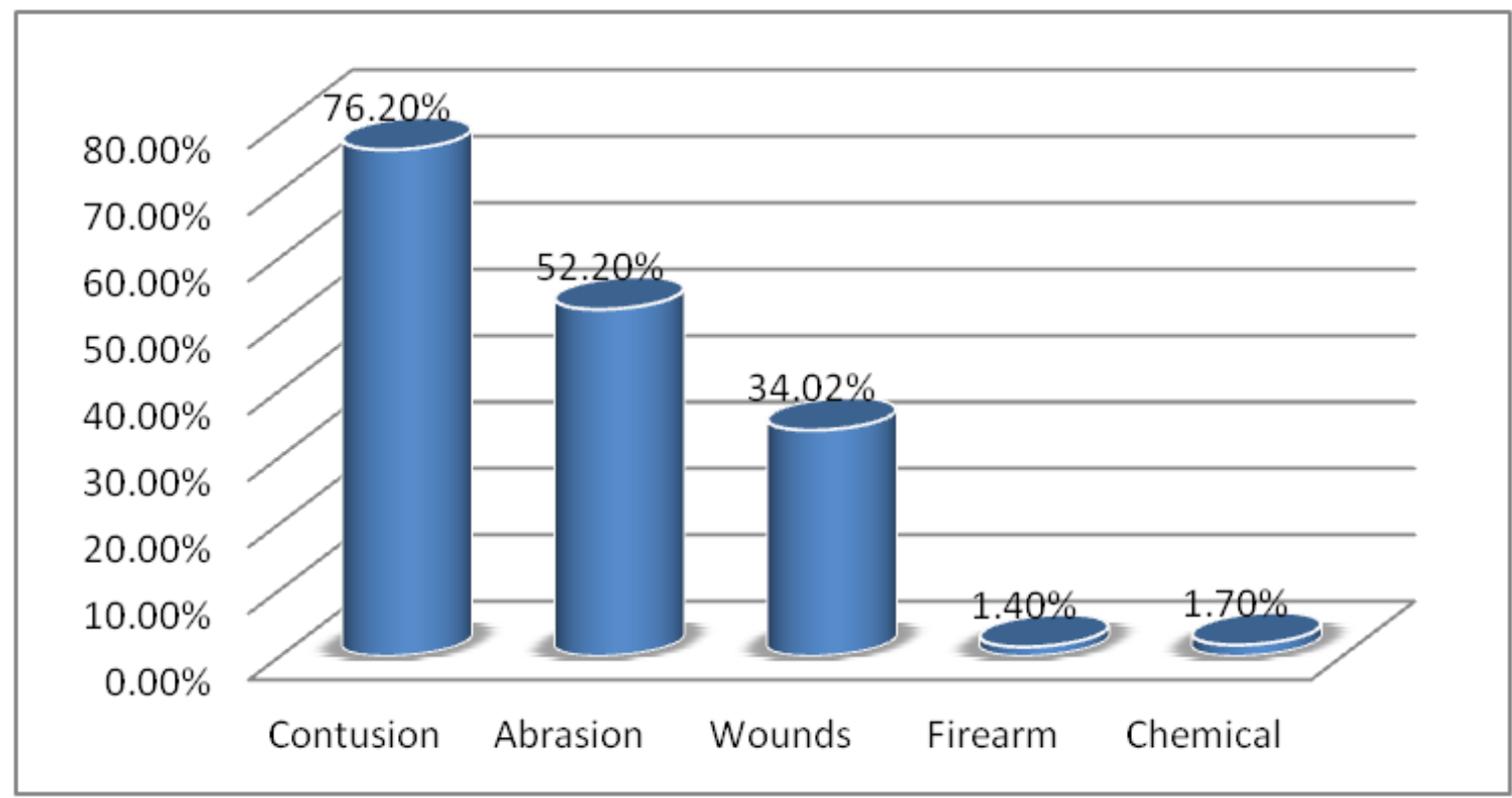

Figure (2): Types of physical violence (Single and combined) 


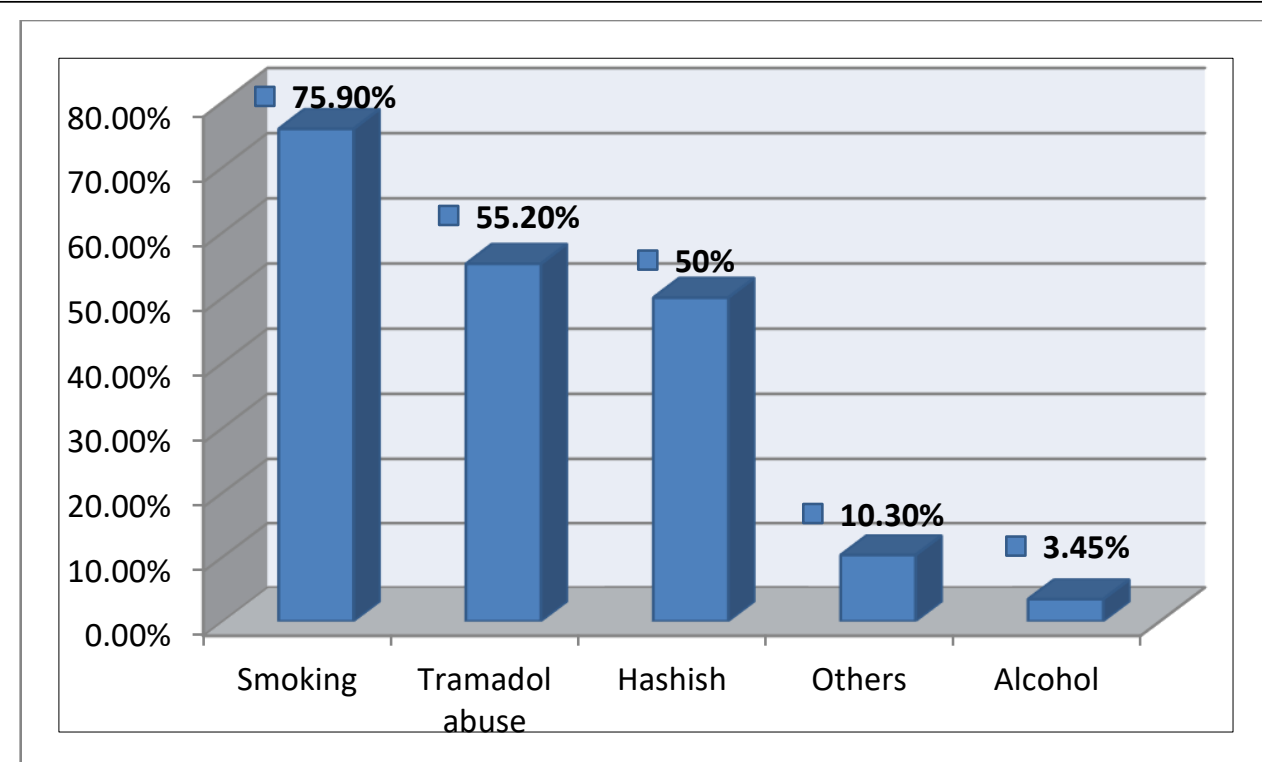

Figure (3): Husband special habits (single and mixed).

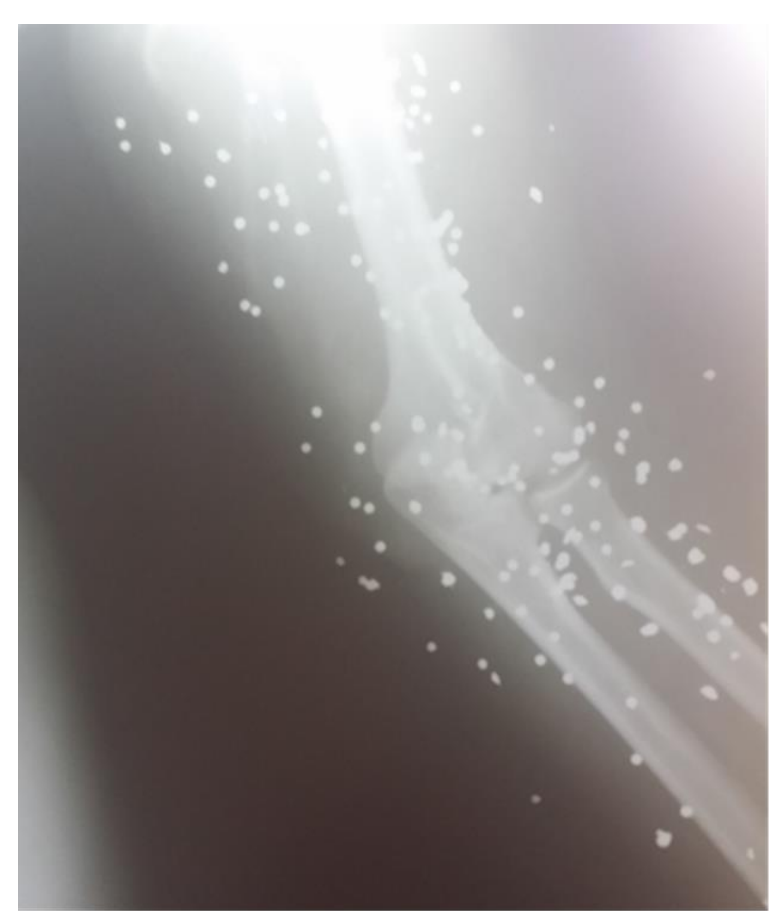

Figure (4): X-Ray of Female Patient 39 Years Old subjected to violence by her Husband Showing Multiple Radio-opaque Shadows along lower part of right humerus and upper part of both bone forearm. 


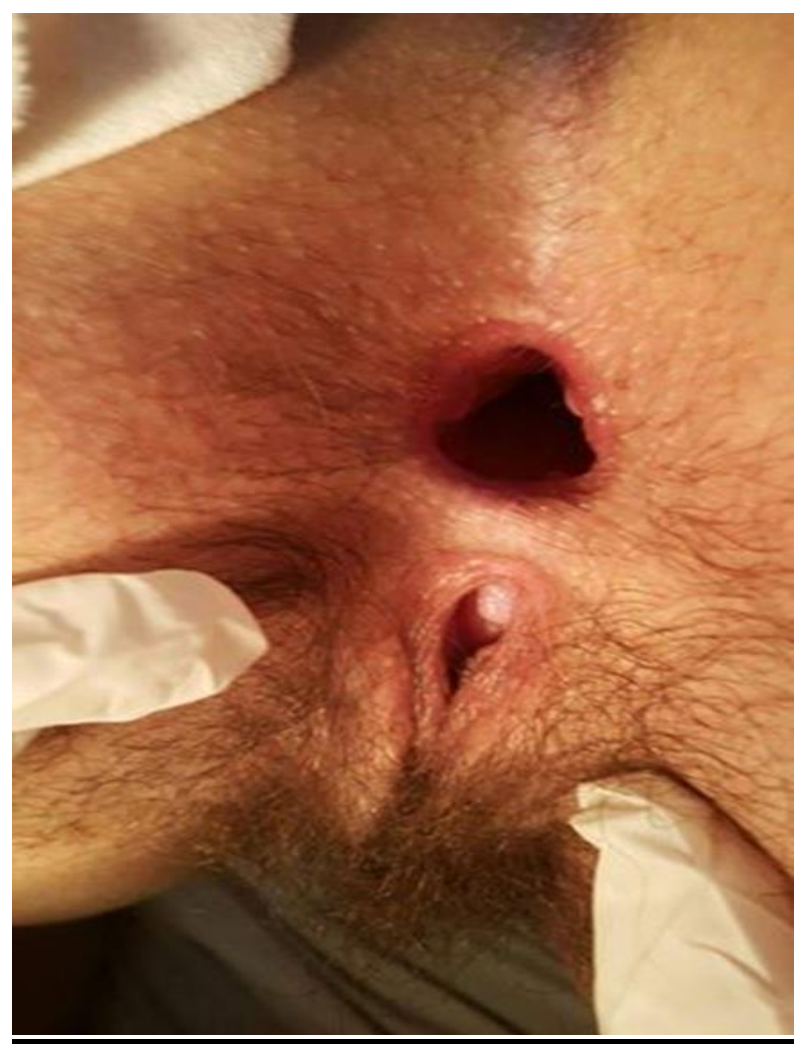

Figure (5): A Photo of Female Patient 18 Years Old subjected to Sexual violence by her husband Showing Dilated Hyperemic Funnel Shaped Anus (Buggery).

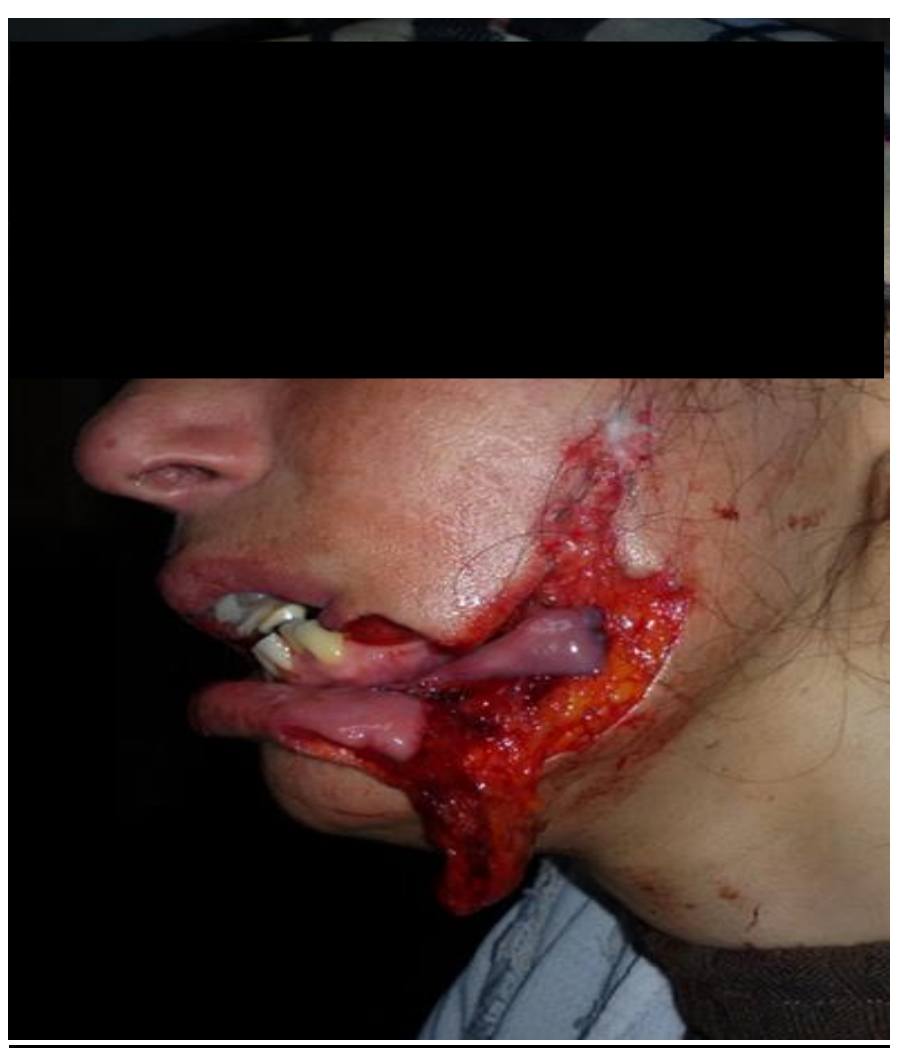

Figure (6): A Photo of Female Patient 34 years old subjected to physical violence by her neighbour showing cut lacerated Wound in left cheek. 


\section{DISCUSSION}

Millions of women all over the world are at risk to different types of violence irrespective of their ages and backgrounds. All countries started to give a very high attention to this problem due to its harmful effects on women health and so their families.

The total number of married women exposed to violence and arrived at forensic medicine department at Menoufia University Hospital to get a primary medico legal report over the study period (between June 2016 and May 2017) was 311 women.

Women aged 21-30-year-old were the highest age group affected (46\%) followed by 31-40 years old (28.3\%), the difference was statistically highly significant (as shown in table 1), this is in accordance with Habib et a l., (2011), Raje (2015) and Mohamadian et a l., (2016) who reported similar findings. According to the 2005 Egypt Demographic and Health Survey, about $50 \%$ of wives aged $15-49$ years old reported that they had been exposed to different types of violence (El-Zanaty and Way 2006). Inexperience and unfamiliarity of young wives with life skills and how to cope with family problems may explain their high exposure to violence, as supported by Jahromi et al. (2016).

The present study showed a highly significant relationship between violence against married women and their occupation, education and residence (table 1). Housewives were the most affected victims (65.9\%), as non-working women have more free time and so more involvement in problems and violence, also have less experience and considered inferior for not sharing in family income. This is in agreement with a study done in
Ethiopia by Gebrezgi et al. (2017) who found that $60.7 \%$ of women included in his study were housewives. Other studies like Habib et al., (2011), Jahromi et al., (2016), Dosary (2016): and Mohamadian et al., (2016) also reported similar findings. In contrast to a study done in Taiwan by Lee et al., (2016) where $87.5 \%$ of the studied women were employees. The contrast may be due to different life style.

Only $12.9 \%$ of the women included in the present study had university graduate and majority of the cases were only read and write (low education) or with moderate education (as shown in table 1). As Low educated women are ignorant about their social rights and so experiencing more violence.

These findings are in agreement with the investigations of Taheri (2013) \& Klink (2013) who found that well educated women are more familiar and have more capacity to cope with problems in surrounding relationships and experience less violence.

Dosary (2016) and Lee et al., (2016) reported contrast findings where most of their cases were highly educated, which may be due to their different study design.

Also, there was a significant relationship between women education (read \& write and moderate education) and frequency of violence from their husbands (as shown in table 2). As mentioned before not well-educated women are ignorant about their rights and have less tendency to report against their husbands, so become silent and bear the repeated violence for fearing of divorce and to keep her family stability. While it was non-significant regarding husband education as it is a society concept, that men are superior 
(irrespective of their level of education), and so can do whatever they want even hitting their wives. In disagreement with Ghimire et al., (2015) who found a strong inverse association of husbands' education and violence against women. The disagreement may be due to different tradition and concept of the society.

More than two thirds of the studied women were rural dwellers (table 1). As women living in rural areas are less educated and not well aware of their equality rights and more affected by traditions and men superiority.

This is in coincidence with Izmirli et al., (2014), Ağçay et al .,(2015) and Gebrezgi et al. (2017), While was in disagreement with Dosary (2016) which may be due to different geographical distribution.

Regarding type of violence $93.6 \%$ of cases reported physical violence (as shown in table 1). Similarly, many studies reported more prevalence of physical violence than sexual one (Afifi et al., 2011; Habib et a 1., 2011; Ghosh, 2013; Diégueza et al., 2015;Semahegn and Mengistie 2015;Reed et al.,2016;). Sexual violence was found more prevalent by Jahromi et al., (2016) and this disagreement may be due to different cultures and traditions.

Concerning physical violence, was mainly by blunt agents, as it was commonly in the form of beating, slapping, pushing or hitting by objects, and this was similar to findings concluded by Gebrezgi et al. (2017). While Sexual violence was mostly in the form of buggery and this indicates less religious and cultural awareness.

Contusions were the commonest physical injury (76.2\%) (As shown in figure 2), and this is supported by Fong et al., (2016) who found that Bruise was $60 \%$.

According to the legal classification of wounds (figure 1), $91.4 \%$ of physical injuries were simple, as supported by Diégueza et al., (2015) who reported that minor acts of physical violence were the commonest mechanisms of assault resulting in mild injuries in the face and upper limbs mainly. Similarly, Oliveira et al., (2014) found that most of their cases had slight injuries.

Social problems were commonly the reasons for violence against married women in the present study. Tokuç et al., (2010) Sinha et al., (2012) and Mavrikiou et al., (2014), also observed that less social support and low socioeconomic status are the risk factors for violence against women.

$69.8 \%$ of the cases were victims to non-husband assailant while $30.2 \%$ were to their husbands (table 1). According to Bennett et al., (2000), women all over the world experience different types of violence by neighbours, close and extended family members, acquaintances, and by men in power and authority positions such as police and soldiers.

The less prevalence of husband perpetrator in the present study could be due to silent suffer of most wives without seeking help to prevent or stop the violence by their husbands as they consider it as a family matter and they are embarrassed to tell about it or to make a report against them, and this is in accordance with Monazea and Abdel Khalek (2010) .Also in agreement with Alzahrani et al.,(2016) who found that only a minority of abused wives included in his investigation made a notification to the 
police or to a judge against their husbands.

21-30 years old assailants were more involved in violence against married women than other age groups (table 1), also this age was a significant risk factor for frequency of husband violence against their wives (table 2). As the high activity of youths, their low experience, poor coping with life, and social \& intellectual immaturity make them more violent. Jahromi et al., (2016) concluded similar results.

More than half of women in this study exposed to violence outdoor $(60.1 \%)$ as more than two thirds of the cases were victims to non-husband assailant as neighbours. In contrast to Fong et al., (2016), who reported that $56.8 \%$ of their cases were exposed to violence at home. The contrast may be due to different study design (Adult femicide victims).

There was a statistically significant difference between duration of marriage ( $<5$ years) and frequency of violence against wives (table 2 ). The finding quietly agrees with a study done in northern Saudi community by Abo-Elfetoh and Abd El-Mawgod (2015) who found that $<10$ years was the commonest marriage duration associated with Physical violence.

Also, number of children (>3) was a significant risk factor for violence frequency (table 2), as a large number of children increases the social and economic burden on married couple. Similarly, to Anes Jellali et al., (2015) who observed that children number (>3) was one of the main associations with violence against married women.

Repeated violence against wives was more in non-working husbands and the difference was statistically significant (table 2). Jobless husband can't provide the requirements of his home and so more problems in family resulting in violence. Semahegn and Mengistie, (2015) stressed on association of occupation with Domestic violence against women. Oliveira et al., (2014) found that $72.4 \%$ of male aggressors in their study were free workers with little income.

The present study showed significant association of husband special habits (smoking and other substance abuse) with repeated violence against their wives (table 2). Smoking was the most common special habits followed by tramadol abuse, hashish, other drugs (benzodiazepine, codeine) and alcohol (figure 3). In accordance to Oliveira et al., (2014) most of male aggressors in their study were illegal drug users. Alzahrani et al., (2015) similarly found drugs addiction and alcohol association with violence. Also Semahegn and Mengistie (2015) supported association of special habit with violence against women but with alcohol consumption and chat chewing. While Sinha et al., (2012) \& Gebrezgi et al., (2017) concluded association with alcohol addiction. The prevalence of alcohols in these studies which is different from the present study due to drinking of alcohol frequently in their countries as it is considered as a habitual life style.

\section{CONCLUSION}

The young aged married couple, non-working husband, large number of children, short duration of marriage are risk factors for violence against married women. Physical violence by blunt instrument was the most common type of violence. Majority of injuries were Simple. 
Low level of female education and husbands have special habits are the most dependent factors increase the frequency of husband violence against their wives.

\section{REFERENCES}

Abo-Elfetoh, N.M. and Abd ElMawgod, M.M. (2015): Violence against wives: a silent suffering in northern Saudi community. J Egypt Public Health Assoc , 90(3):87-93.

Afifi, Z.E.; Al-Muhaideb, N.S.;Hadish, N.F.; Ismail, F.I.; Al-Qeamy, F.M. (2011): Domestic violence and its impact on married women's health in Eastern Saudi Arabia. Saudi Med J, 32(6):612-20. Ağçay, G.; Inanici, S .Y. ; Çolak, B.; İnanici, $M$.A. (2015): Risk factors for violence against women by intimate partners in Sakarya, Turkey. Journal of Forensic and Legal Medicine, 36: 37-42.

Alzahrani, T.A.; Abaalkhail, B.A., and Ramadan, I.K. (2016): Prevalence of intimate partner violence and its associated risk factors among Saudi female patients attending the primary healthcare centers in Western Saudi Arabia. Saudi Med J, 37(1):96-99.

Anes Jellali, I.; Jellali, M.A.; Gataa, R.; Mechri, A. (2015): Violence against women in the marriage: Cross-sectional study in the family planning clinic Monastir. Tunis Med, 93(8-9):516-522.

Diégueza, A.R.; Rivas, N.P.; Barús, J.I.M.; Portomeñe, F.V.; Calvo, M.S.R. (2015): Intimate partner violence against women in Spain: A medico-legal and criminological study. Journal of Forensic and Legal Medicine, 34: 119-126.
Bennett, L. R. ;Manderson, L. and Astbury, J. (2000): Mapping a Global Pandemic: Review of Current Literature on Rape, Sexual Assault and Sexual Harassment of Women, Consultation on Sexual Violence Against Women, Global Forum for Health Research, Geneva, Switzerland, 2000.

Bonomi, A.E.; Thompson, R.S.; Anderson, M.; Reid, R.J.; Carrell, D.; Dimer, J.A. et al (2006): Intimate partner violence and women's physical, mental, and social functioning. Am Prev Med, 30:458-466.

Dosary, A. H. (2016): Health Impact of Domestic Violence against Saudi Women: Cross Sectional Study. International Journal of Health Sciences, Qassim University, 10:2.

El-Zanaty, F. and Way, A. (2006): 'Egypt Demographic and Health Survey', March (http://dhsprogram.com/pubs/pdf/F R176/FR176.pdf).

Fong, W .L.; Pan, C. H.; Lee, J.; Lee, T .T.; Hwa, H .L. (2016): Adult femicide victims in forensic autopsy in Taiwan: A 10-year retrospective study. Forensic Science International, 266: 80-85.

Gebrezgi, B. H.; Badi, M. B.; Cherkose, E. A. ; Weldehaweria, N .B. (2017): Factors associated with intimate partner physical violence among women attending antenatal care in Shire Endaselassie town, Tigray, northern Ethiopia: a cross-sectional, July 2015.Reproductive Health ,14(1):76.

Ghimire, D. J.; Axinn, W. G. and Smith-Greenaway, E. (2015): Impact of the spread of mass 
education on married women's experience with domestic violence. Social Science Research, 54: 319331.

Ghosh, S. (2013): Violence against married women in India: Can the data tell us anything? http://ideasforindia.in//article.aspx? article $=$ Violence-against-marriedwomen-in-India-Can-the-data-tellus-anything.

Habib, S. R.; Abdel Azim, E. K.; Fawzy, I .A. ; Kamal, N. N. ; Sherbini, A M. (2011): Prevalence and Effects of Violence Against Women in a Rural Community in Minia Governorate, Egypt. J Forensic Sci, 56: 6.

Izmirli, G. O.; Sonmez, Y. and Sezik, M. (2014): Prediction of domestic violence against married women in southwestern Turkey. International Journal of Gynecology \& Obstetrics, 127(3): 288-292.

Jahromi, M. K.; Jamali, S.; Koshkaki, A. R., Javadpour, S. (2016): Prevalence and Risk Factors of Domestic Violence against Women by Their Husbands in Iran. Global Journal of Health Science, 8: 5.

Jahromi, M K.; Jamali, S.; Koshkaki, A R.; Javadpour, S. (2016): Prevalence and Risk Factors of Domestic Violence Against Women by Their Husbands in Iran. Global Journal of Health Science, 8(5):175-183.

Klink, C. (2013): Coping with Life Challenges. Translated by $\mathrm{M}$. Narimani, \& E. Valizadeh, Mashhad: Astan Qods Publications. 240.

Lee, F. H.; Yang, Y. M.; Wang, H. H.; Huang, J. J.; Chang, S C. (2015): Conditions and Patterns of
Intimate Partner Violence among Taiwanese Women. Asian Nursing Research, 9: 91-95.

Mavrikiou, P. M.; Apostolidou, M.; Parlaliscre, S. K. (2014): Risk factors for the prevalence of domestic violence against women in Cyprus. The Social Science Journal, 51(2): 295-301.

Michael, A.; Koenig, R.; Stephenson, S.; Ahmed, S.J.; Jejeebhoy, J. (2006): Individual and contextual determinants of domestic violence in North India. American Journal of Public Health. 96(1):132-138.

Mohamadian, F.; Hashemian, A.; Bagheri, M.; Moghadam, A. D. (2016): Prevalence and Risk Factors of Domestic Violence against Iranian Women :A CrossSectional Study. Korean J Fam Med, 37:253-258.

Monazea, E. M. and Abdel Khalek, E. M. (2010): Domestic Violence High in Egypt, Affecting Women's Reproductive Health. http://www.prb.org/Publications/Ar ticles/2010/domesticviolenceegypt.aspx.

Patel, V.; Krikwood, B.R.; Pednekar, S.; Pereira, B.; Barros, P.; Fernandes, J. et al (2006): Gender disadvantage and reproductive health risk factors for common mental disorders in women: a community survey in India. Arch Gen Psychiatry, 63:404-413.

Petersen, R.; Gazmararian, J. and Andersen Clark, K. (2001): Partner violence: implications for health and community settings. Women's Health Issues 2001, 11:116-125.

Raje, V. (2015): Study of Domestic Violence against Married Women in Western Maharashtra of India. 
British Journal of Education, Society\& Behavioral Science, 10(1): 1-10.

Reed, E.; Saggurti, N.; Donta, B.; Ritter, J.; Dasgupta, A.; Ghule, M. et al (2016): Intimate partner violence among married couples in India and contraceptive use reported by women but not husbands. International Journal of Gynecology \& Obstetrics, 133(1): 22-25.

Semahegn, A. and Mengistie, B. (2015): Domestic violence against women and associated factors in Ethiopia; systematic review. Reprod Health, 29; 12:78.

Oliveira, S.F.; Lima Cardoso, K.R.; Almeida, C.A.P.; Cardoso, L.R.; Gutfilen, B. (2014): Violence against women: Profile of the aggressors and victims and characterization of the injuries. A forensic study. Journal of Forensic and Legal Medicine, 23: 49-54.

Sinha, A.; Mallik, S.; Sanyal, D.; Dasgupta, S.; Pal D.; Mukherjee, A. (2012): Domestic violence among ever married women of reproductive age group in a slum area of Kolkata. Indian J Public Health, 56(1):31-36.

Majumdar, S. (2006): In India, Domestic violence rises with education: Internet: Run Date 11/06/03: Download; 2006.

Taheri, S. (2013): A Study of the Prevalence and Quality of Physical violence against Women. Digest of the papers presented at the first Convention of Health Education and Promotion, Tehran, 52.

Tokuç, B.;Ekuklu, G. and Avcioğlu, S. (2010): Domestic Violence Against Married Women in Edirne. Journal of Interpersonal Violence, 25 (5): 832-847.

United Nations (2006): Ending violence against women: From Words to Action. United Nations; 2006.

Watts, C. and Zimmerman, C. (2002): Violence against women: global scope and magnitude. Lancet 2002, 359:1232-1237.

Yildizhan, R.;Adali, E.; Kolusari, A.; Kurdoglu, M.; Yildizha, B.; Sahin, G. (2009):Domestic violence against infertile women in Turkish setting. Int $\mathbf{J}$ Gynecol Obstet 2009, 104:110-112. 
دراسة مستقبلية لبعض الجوانب الطبية الثرعيه للعنف ضد النساء المتزوجات اللاتي وصلن إلى المي

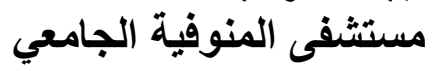

$$
\begin{aligned}
& \text { د. علا عبد الهادي سويلم د.ستهم السيد العجمي }
\end{aligned}
$$

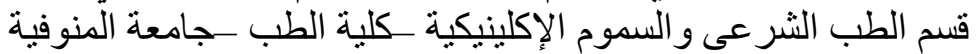

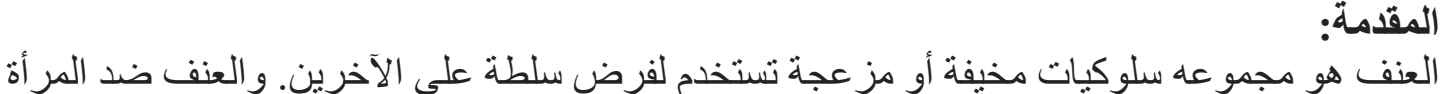

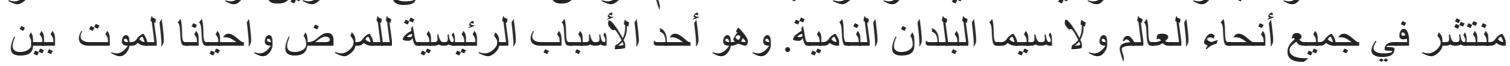

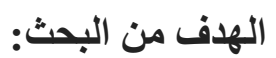

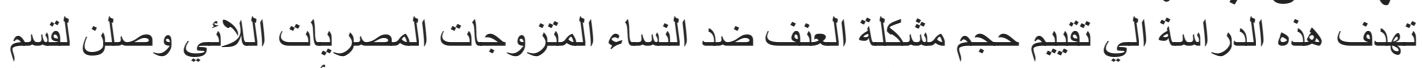

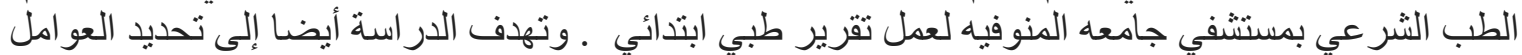

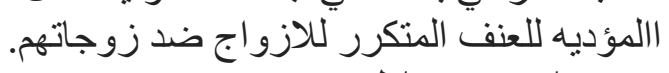

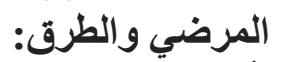

أجريت الدر اسة على الطى 311 امر أة متزوجة بعد اخذ رايهم عن طريق ملء استبيان بتضمن مجمو عه من

الاسئلة الخاصه بهذا الموضوع.

النتائج:

وجدنا أن العنف ضد المر أة يرتبط بشكل أكبر بالنساء اللواتي تتر اوح أعمار هن بين 21 و 30 سنة ويجدن

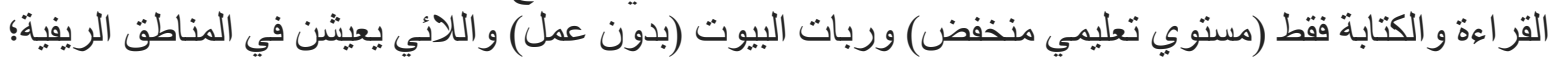

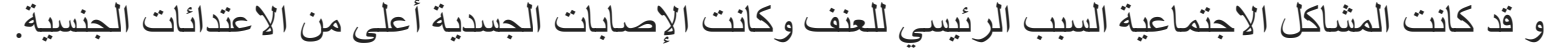

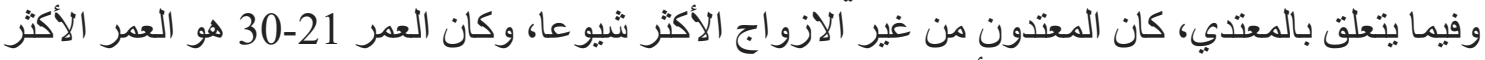

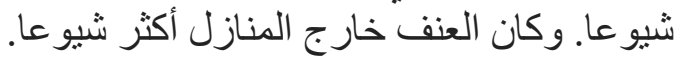

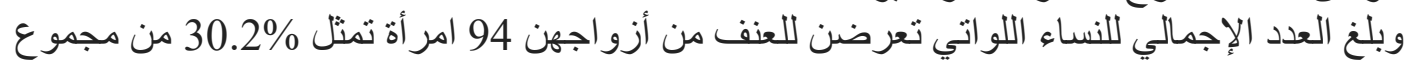

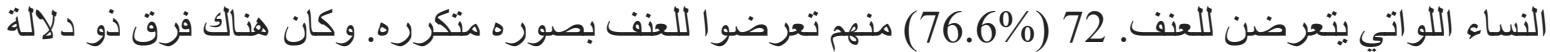

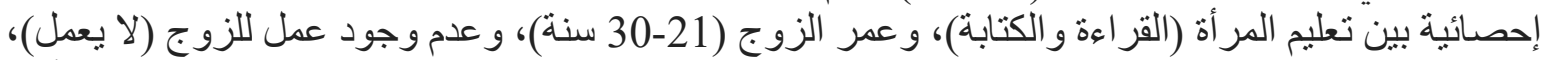

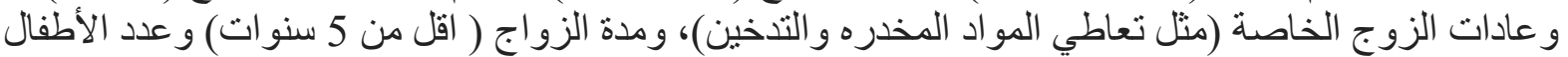
(3 أطفال او اكثر) و تكر ار العنف الزوجي. 